\title{
Chirurgia plastyczna tęczówki. Część 2. Chirurgia z użyciem implantów tęczówkowych oraz techniki łączone. Opisy przypadków
}

\author{
Iris plastic surgery. Part 2. Surgery with iris implants and combined techniques. A case series report
}

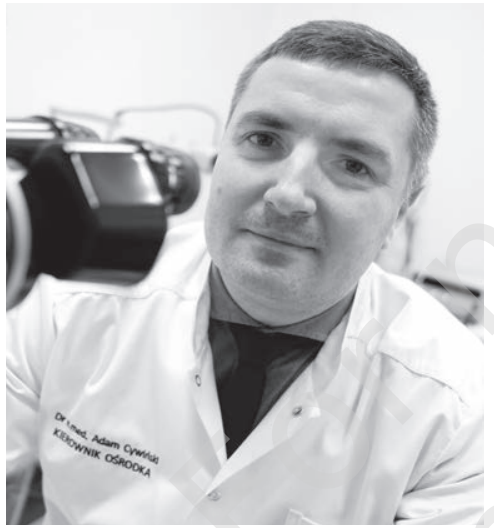

N A J W A Ż N IEJSZE Zastosowanie implantów tęczówkowych pozwala na uzupełnienie praktycznie wszystkich ubytków tęczówki, przy czym najlepszy efekt wizualny daje użycie tęczówki sztucznej.

\section{H I G H L I G H T S}

The use of iris implants allows correction of practically all iris defects, with the best visual effect obtained with the use of artificial iris.
Adam Cywiński

Śląskie Centrum Leczenia Oczu w Żorach Kierownik: dr n. med. Adam Cywiński

\section{STRESZCZENIE}

Artykuł opisuje możliwości oraz wskazania do chirurgicznej korekcji ubytków tęczówki z użyciem implantów tęczówkowych oraz ich połączeń z techniką szycia tęczówki na przykładzie pięciu przypadków pacjentów z materiału własnego autora. Wszyscy z nich wyrazili świadomą zgodę na przeprowadzone procedury medyczne. Używając implantów tęczówki częściowych oraz całkowitych, a także sztucznej tęczówki, można skorygować praktycznie wszystkie ubytki oraz niedoskonałości tęczówki. Według autora implanty tęczówki powinny być stosowane w korekcji tych ubytków, których nie można uzupełnić z użyciem technik szycia. W niniejszej pracy przedstawiono pięć przypadków chirurgicznej rekonstrukcji zarówno wrodzonych, jak i nabytych defektów tęczówki.

Słowa kluczowe: sztuczna tęczówka, implanty tęczówki, zniekształcenie źrenicy, uraz oka, ubytki tęczówki

\section{ABSTRACT}

The article describes possibilities and indications for surgical correction of iris defects using artificial implants and their combinations with suture techniques in five cases from the author's own material. All patients gave informed consent for medical procedures. Using partial or total implants of the iris, including artificial iris, we can correct almost all iris losses and imperfections. Iris implants should be considered if simple suture of the iris is insufficient in obtaining the intended effect. This article presents five cases of surgical iris reconstrucion both in congential and acquired iridial defects.

Key words: artificial iris, iris implants, pupil deformation, ocular trauma, iris defects 


\section{WSTĘP}

Implanty tęczówkowe, w tym tęczówka sztuczna, to stałe elementy dynamicznie rozwijającego się rynku chirurgii naprawczej oka. Coraz doskonalsze, dają wiele możliwości leczenia ubytków tęczówki, zbyt szerokiej źrenicy czy całkowitego braku tęczówki [1]. Wskazania do ich zastosowania autor artykułu upatruje w stanach, w których ubytki tęczówki są zbyt duże, aby uzupełnić je, stosując techniki szycia. Obecnie istnieje wiele firm zajmujących się produkcją implantów, w tym Morcher, HumanOptics, Ophtec czy Reper. W poprzednim artykule, który ukazał się w „OphthaTherapy”, zostały przedstawione wskazania do zaopatrzenia ubytków tęczówki z użyciem technik szycia [2]. Technika szycia znalazła także zastosowanie $\mathrm{w}$ autorskiej metodzie zamknięcia wrodzonego ubytku - kolobomy tęczówki. Co ważne, używając tej techniki, nie ma potrzeby usuwania soczewki własnej [3]. W wielu przypadkach jednoczesne zastosowanie obu technik, tj. implantu tęczówkowego oraz szycia tęczówki, daje najkorzystniejsze efekty. Ubytki tęczówki mogą dotyczyć także jej struktury. Ubytek w strukturze tęczówki może dotyczyć nabłonka barwnikowego, mięśnia zwieracza tęczówki lub obu. Zanik nabłonka barwnikowego oprócz zmiany koloru (najczęściej na jasnoniebieski) powoduje utratę najważniejszej funkcji, tj. ochrony wnętrza oka przed nadmierną ekspozycją światła. Towarzyszący mu światłowstręt jest bardzo uciążliwy, co wymaga zaopatrzenia. Uszkodzenie zwieracza źrenicy daje podobne objawy, a dodatkowo może powodować znaczące obniżenie ostrości i jakości widzenia. Autor zwraca uwagę na ważny szczegół w korekcji ubytków tęczówki. Używając technik szycia, można uzupełnić tylko wybrane ubytki, stosując implanty tęczówki - praktycznie każdy. Dokonując wyboru pomiędzy implantem tęczówki a techniką szycia, należy pamiętać, iż w każdym przypadku, kiedy chcemy wprowadzić implant tęczówki, musimy usunąć soczewkę własną. Niepotrzebnie zwiększa to zakres, a tym samym koszt zabiegu.

\section{IMPLANTY CZĘŚCIOWE TĘCZÓWKI}

Ich wybór jest olbrzymi. Wielkość implantu dostosowuje się do wielkości ubytku oraz do jego lokalizacji [4]. W ten sposób możemy uzupełnić ubytki niezbyt duże, obejmujące 1-3 h zegarowe oraz bardzo duże, w tym całkowity brak tęczówki. Małe ubytki mogą się pojawić np. po wycięciu guza tęczówki, nieplanowanej, zbyt dużej irydektomii lub pourazowym oderwaniu tęczówki od nasady. Implant korygujący płytki ubytek zlokalizowany u podstawy tęczówki wymaga mniejszego cięcia w celu wprowadzenia do wnętrza oka niż implant większy, korygujący ubytek w jej części centralnej (ryc. 1).

\section{RYCINA}

Częściowe implanty tęczówki firmy Morcher. A. Stosowane w korekcji „płytkich” ubytków obwodowych. B. Stosowane w korekcji większych ubytków centralnej części tęczówki.



Implanty w kształcie pierścieni mają zastosowanie, gdy uszkodzony jest zwieracz źrenicy powodujący jej trwałe, nieodwracalne poszerzenie. Patologia ta często stanowi następstwo ostrego ataku jaskry lub też urazu tępego gałki ocznej. W każdym przypadku stosuje się dwa pierścienie. Implanty te mogą być wprowadzone do torebki soczewki. Wówczas należy pamiętać o wykonaniu odpowiedniej wielkości kapsuloreksji, większej niż podczas standardowego usunięcia zaćmy. Kolejny model pierścieni umieszcza się w rowku rzęskowym wobec braku podpory w postaci torby soczewki (ryc. 2). Model ten wymaga wykonania większego cięcia rogówkowego czy twardówkowego (ok. 4-5 mm) w celu wprowadzenia do wnętrza oka [5]. Implanty korygujące brak tęczówki mają zastosowanie w przypadkach znacznego ubytku tęczówki tworzącej brzeg źrenicy lub całkowitego braku tęczówki. Ten ostatni nierzadko towarzyszy bardzo ciężkim urazom oka, które dodatkowo uszkadzają rogówkę, soczewkę oraz elementy odcinka tylnego oka. W przypadku uszkodzenia soczewki i potrzeby jej usunięcia można zastosować implanty złożone, jednocześnie korygujące bezsoczewkowość.

RYCINA 2

Częściowy implant firmy Morcher stosowany w przypadku

szerokiej źrenicy, niereagującej na światło. Korekcja wymaga

użycia dwóch implantów jednocześnie, których brzegi,

zachodząc na siebie, tworzą jednolitą strukturę.

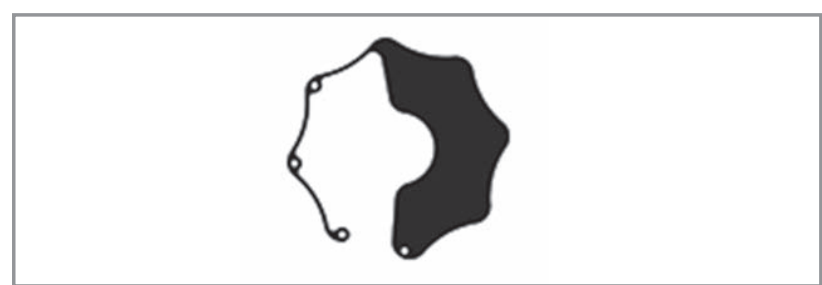

Wszystkie wyżej wymienione implanty mają jedną wspólną cechę. Są koloru czarnego. Sprawia to, że w przypadku znaczących ubytków widać znaczną różnicę w kolorze tęczówki oka zdrowego oraz poddanego leczeniu. 
Wielkość implantu decyduje o wielkości cięcia, przez które wprowadzony jest do wnętrza oka. Te najmniejsze wymagają cięć na poziomie $3 \mathrm{~mm}$, największe - ponad $10 \mathrm{~mm}$. Największych cięć wymagają implanty sztywne, niezwijalne, korygujące całkowity brak tęczówki oraz modele złożone, dodatkowo korygujące bezsoczewkowość oka. Duże cięcie jest dość obciążające dla oka, nierzadko pourazowego.

Sztuczna tęczówka to produkt najbardziej zaawansowany w chirurgii naprawczej oka. Wyglądem przypomina zdrową tęczówkę. Zbudowana z elastycznego, zwijalnego materiału, może być wprowadzona do oka przez cięcie nie większe niż $3 \mathrm{~mm}$. Gotowe implanty sztucznej tęczówki mają określony kolor, tak więc nie zawsze można dopasować je do koloru oka zdrowego. Ich cena jest niższa od ceny tęczówek kastomizowanych, których kolor oraz fakturę dobiera się w oparciu o kolor tęczówki oka zdrowego. Koszt tych produktów wielokrotnie przekracza cenę standardowego, czarnego implantu. W przypadku braku soczewki można wybrać model implantu dodatkowo korygujący bezsoczewkowość [6]. Jego wartość oblicza się podobnie jak wartość soczewki wewnątrzgałkowej. Zróżnicowana budowa sztucznej tęczówki pozwala na jej podszycie lub umieszczenie w rowku rzęskowym (ryc. 3). Możliwość trwałej fiksacji sztucznej tęczówki nabiera dużego znaczenia w przypadku operacji oka z towarzyszącym oczopląsem, często obserwowanym u pacjentów z wrodzonym brakiem tęczówki. Jest to wyzwanie dla chirurga, głównie z uwagi na ryzyko wystąpienia powikłań pooperacyjnych, wynikających z zaburzenia w zakresie budowy pogranicza rogówki i tęczówki [7].

\section{RYCINA 3}

Sztuczna tęczówka firmy Reper, którą umieszcza się w rowku rzęskowym.

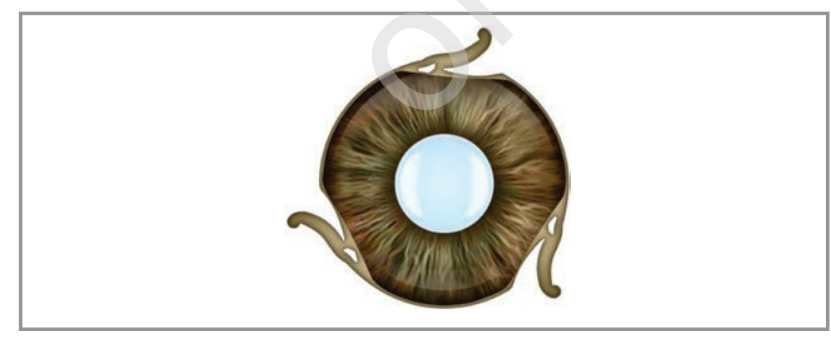

Podsumowując część teoretyczną, w przypadku optymalnej korekcji ubytku tęczówki dąży się do uzyskania stanu, który pod względem funkcji oraz wyglądu będzie najbardziej zbliżony do oka zdrowego. Dlatego Autor, biorąc pod uwagę doświadczenia własne, w pierwszej kolejności preferuje wykorzystanie tęczówki własnej pacjenta i stosowanie technik jej szycia, jeżeli jest to tylko możliwe. Łączenie tańszych, czarnych implantów tęczówki z techniką szycia daje także korzystny efekt wizualny, a w przypadku całkowitego braku tęczówki wybór sztucznej tęczówki to najlepsza opcja korekcji.

\section{OPISY PRZYPADKÓW}

\section{Przypadek 1. Fiksacja przeztwardówkowa złożonego implantu tęczówki, jednocześnie korygującego bezsoczewkowość oka}

Mężczyzna, lat 34. Stan po urazie przenikającym oka prawego. Duże ciało metaliczne spowodowało uszkodzenie rogówki oraz całkowite uszkodzenie tęczówki i soczewki. Przyczyny operacji to znaczny światłowstręt oraz bardzo słaba ostrość wzroku do dali na poziomie 0,02 (Snellen). Badanie dna oka nie wykazało patologii w obrębie tylnego bieguna. Zabieg naprawczy wykonano 8 lat temu. Użyto implantu złożonego, wymagającego podszycia (ryc. 4). Po zabiegu ostrość wzroku do dali bez korekcji osiągnęła wartość 0,6. Światłowstręt ustąpił. Czarny kolor implantu oraz duże cięcie twardówkowe wielkości $10 \mathrm{~mm}$ to jedyne mankamenty tego zabiegu. Należy wziąć pod uwagę, że w przypadku całkowitego ubytku tęczówki implant podlegający podszyciu może ulegać samoistnemu przesunięciu wewnątrz oka. Aby tego uniknąć, można wybrać model, który przyszywa się do twardówki w czterech miejscach zamiast standardowych dwóch (ryc. 5). Planując ten zabieg obecnie, jako leczenie $\mathrm{z}$ wyboru, autor zaproponowałby pacjentowi wszczep implantu złożonego, tj. kastomizowanej sztucznej tęczówki korygującej bezsoczewkowość.



\section{RYCINA 5}

\section{Implant tęczówki z czterema punktami fiksacyjnymi pozwalający uzyskać większą stabilność w oku.}



W niektórych przypadkach wszycie implantu tęczówkowego trzeba połączyć z zabiegiem przyłożenia odwarstwionej siatkówki. Jeżeli zabieg wymaga użycia oleju silikonowego, w celu uniknięcia powikłań pooperacyjnych można wybrać model implantu, który ma w dolnej części optyki wycięcie pełniące funkcje irydektomii modo Ando (Morcher).

W każdym przypadku kwalifikacji do zabiegów naprawczych tęczówki nie należy zapominać o ocenie stanu rogówki (badanie komórek śródbłonka), odcinka tylnego gałki ocznej oraz pomiarze ciśnienia wewnątrzgałkowego. Znajomość tych informacji pozwala w bardziej precyzyjny sposób ocenić szanse na uzyskanie przewidywanego efektu leczenia.

\section{Przypadek 2. Zabieg łączący fiksację złożonego} implantu tęczówkowego, korygującego jednocześnie bezsoczewkowość z plastyką tęczówki własnej

Taki typ zabiegu pozwala na uzyskanie lepszego efektu kosmetycznego, który dla wielu pacjentów ma ogromne znaczenie w procesie leczenia.

Pacjent, lat 77. Uraz tępy oka 20 lat temu spowodował uszkodzenie zwieracza źrenicy oraz zmętnienie soczewki. Po usunięciu zaćmy wprowadzono soczewkę wewnątrzgałkową typu „sputnik”, wymagającą wykonania kilku irydektomii. Przez cały okres pooperacyjny pacjent uskarżał się na znaczny światłowstręt oraz słabą ostrość i jakość widzenia. Badanie konsultacyjne wykazało obecność kilku dużych otworów w tęczówce oraz skośne ustawienie wszczepionej soczewki. Średnica otworu źreniczego osiągała wartość ok. $9 \mathrm{~mm}$. Nie stwierdzono patologii na dnie oka. Usunięto soczewkę sztuczną oraz wprowadzono implant złożony, korygujący brak tęczówki i bezsoczewkowość. Dodatkowo zmniejszono średnicę źrenicy pacjenta, poprawiając w ten sposób efekt kosmetyczny (ryc. 6). Światłowstręt ustąpił po zabiegu. Ostrość wzroku do dali z wartości 0,1 poprawiła się do wartości 0,5 (Snellen).
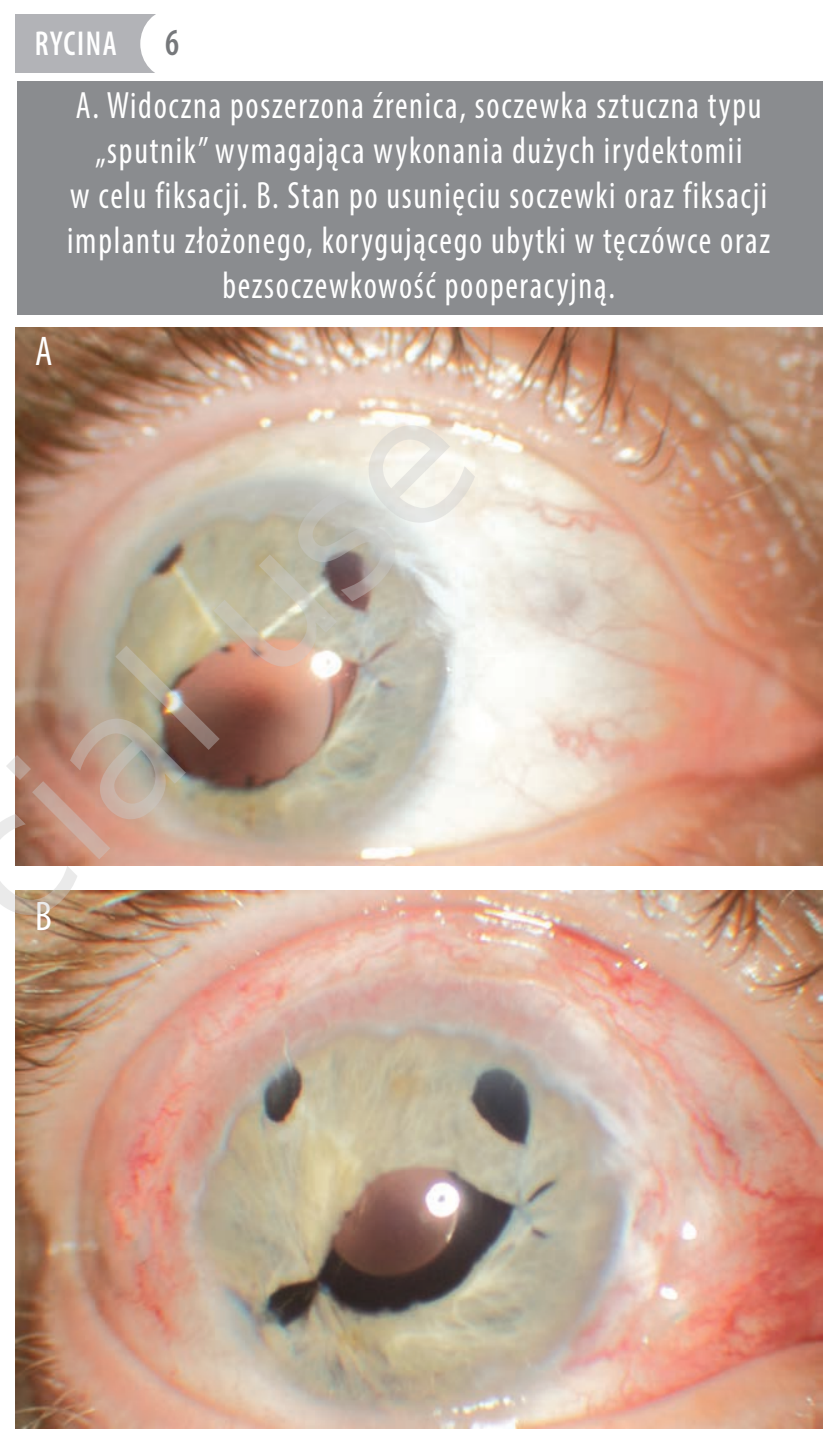

Podobnie jak w poprzednim przypadku duże cięcie twardówkowe jest mankamentem stosowania tego typu implantów, ponieważ może generować znaczny astygmatyzm pooperacyjny. Czarny kolor implantu został przesłonięty tęczówką pacjenta, pozwalając w ten sposób zachować kolor zdrowego oka.

\section{Przypadek 3. Usunięcie zaćmy z następowym wszczepem} soczewki do torebki soczewki oraz użyciem dwóch częściowych implantów w korekcji oka ze stwierdzoną zaćmą oraz z wrodzonym brakiem tęczówki

Pacjentka, lat 46, z wrodzonym brakiem tęczówki została poddana powyższemu zabiegowi. Użyty model implantów powinien być umieszczony w torebce soczewki, przed soczewką sztuczną. Z uwagi na zbyt małą kapsuloreksję, mimo że jej wymiary były standardowe, implanty umieszczono w bruździe rzęskowej, co miało bezpośredni wpływ na poszerzenie otworu źreniczego (ryc. 7). Uzyskano poprawę ostrości wzroku do dali, z wartości 0,06 do 0,2 (Snellen). Objawem często zgłaszanym przez pacjentów 
po wykonaniu tego typu zabiegu jest znaczne zacienienie obrazu.

\section{RYCINA 7}

A. Wrodzony brak tęczówki z towarzyszącą zaćmą - stan przed zabiegiem. B. Częściowy implant tęczówki, w każdym przypadku korekcji stosuje się dwa identyczne elementy.

C. Stan po usunięciu zaćmy oraz wszczepieniu implantów, które po odpowiednim ustawieniu pozwalają uzyskać efekt jednolitej czarnej tęczówki.
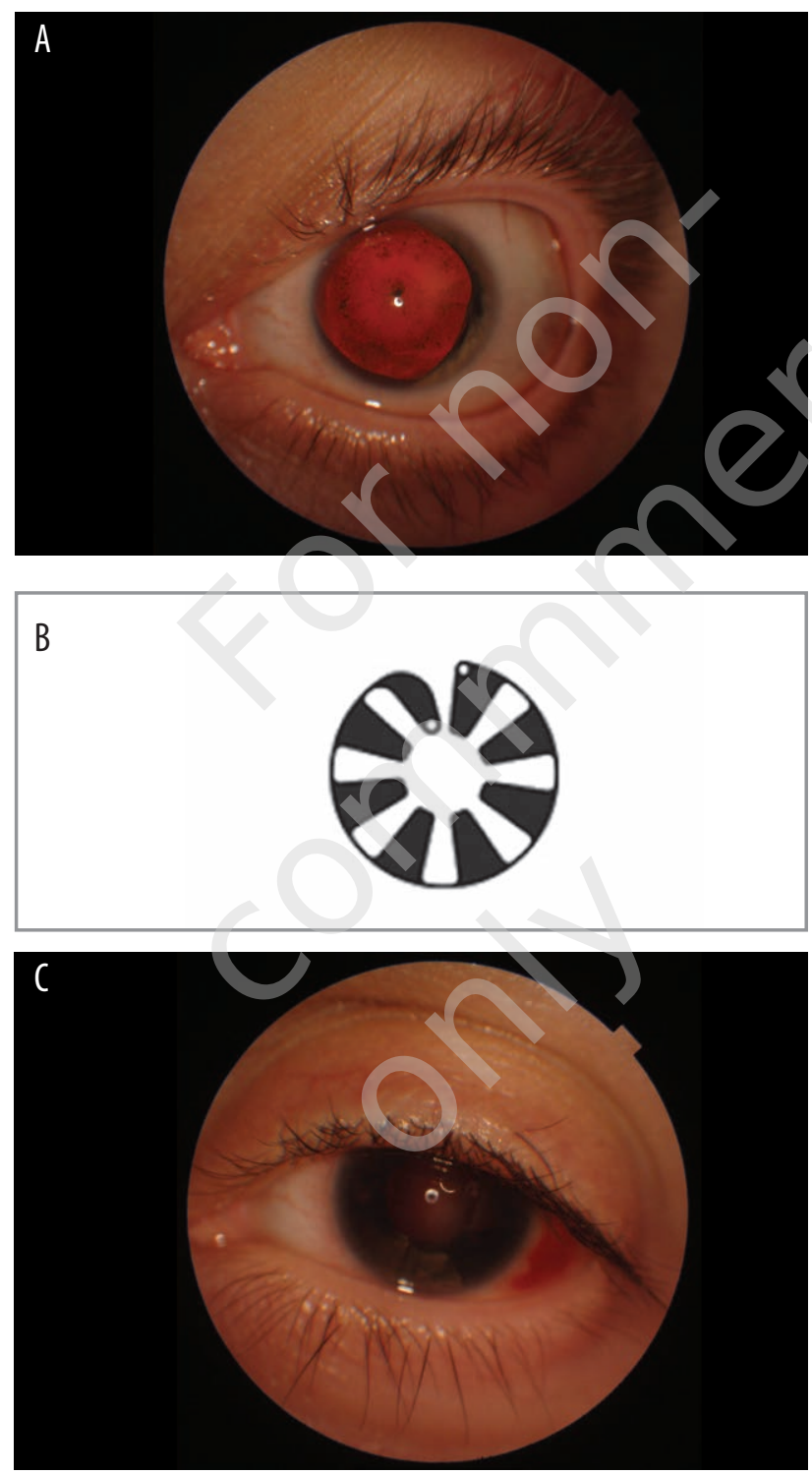

Wrodzony brak tęczówki z towarzyszącą zaćmą można zaopatrzyć na kilka sposobów. Poza wyżej opisanym można użyć implantu złożonego, korygującego brak tęczówki oraz bezsoczewkowość. Przeciwko temu przemawiają brak możliwości umieszczenia soczewki fizjologicznie w torebce oraz potrzeba wykonania bardzo dużego cięcia twardówkowego $(10 \mathrm{~mm})$ w celu wprowadzenia implantu do oka.
Należy dodać, że w obu przypadkach uzyskujemy niezbyt korzystny efekt „czarnej tęczówki”. Biorąc pod uwagę omawiany przypadek, najlepszą opcją leczniczą byłoby jednoczesne usunięcie zaćmy z wprowadzeniem soczewki do torebki oraz wszczepem niekastomizowanej tęczówki sztucznej. Obuoczny, wrodzony brak tęczówki może być zaopatrzony z użyciem implantów tęczówkowych o standardowych kolorach oferowanych przez firmy. Ich cena jest niższa niż cena tęczówki kastomizowanej.

Przypadek 4. Usunięcie zaćmy w połączeniu z wszczepem soczewki do torebki oraz wszyciem sztucznej tęczówki we wrodzonym braku tęczówki

Pacjent ze stwierdzonym wrodzonym brakiem tęczówki oraz z towarzyszącą zaćmą oka lewego został poddany zabiegowi usunięcia zaćmy w połączeniu $\mathrm{z}$ wszczepem soczewki sztucznej do torebki oraz fiksacji przeztwardówkowej niekastomizowanego modelu tęczówki sztucznej. Zabieg wykonano jednoetapowo. Uzyskano poprawę jakości oraz ostrości wzroku, a dzięki wszczepowi sztucznej tęczówki - zadowalający efekt kosmetyczny (ryc. 8).

\section{RYCINA 8}

A. Wrodzony brak tęczówki z towarzyszącą zaćmą - stan przed zabiegiem. B. Niekastomizowany implant sztucznej tęczówki, model do podszycia użyty w trakcie zabiegu. C. Stan po wszyciu sztucznej tęczówki.





Opisana metoda leczenia jest najlepsza w tego typu przypadkach. Alternatywnie można by zastosować wprowadzenie implantu złożonego, tj. sztucznej tęczówki korygującej jednocześnie bezsoczewkowość pooperacyjną. Ta opcja nie jest do końca korzystna, ponieważ soczewka nie jest wprowadzona bezpośrednio do torby. Mając w pamięci to, że nie każde oko reaguje właściwie na obecność obcego materiału, w przypadku potrzeby usunięcia implantu złożonego tęczówkowo-soczewkowego pacjent pozostałby bezsoczewkowy lub wymagałby kolejnego zabiegu wszczepienia soczewki sztucznej. Należy pamiętać, że z czasem torebka soczewki ulega zmętnieniu, przez co tworzy się naturalna bariera, spełniająca funkcję ochronną przed nadmierną ekspozycją wnętrza oka na światło, podobnie jak tęczówka. Opcja wszczepienia implantu złożonego, tęczówkowo-soczewkowego, powinna być zarezerwowana dla oczu, w których nie ma podpory dla soczewki sztucznej pod postacią torebki soczewki.

Przypadek 5. Fiksacja przeztwardówkowa złożonego implantu tęczówkowego korygującego bezsoczewkowość w połączeniu z plastyką tęczówki zmniejszającą średnicę źrenicy

Mężczyzna, lat 79, doznał urazu przenikającego oka prawego, który doprowadził do usunięcia soczewki, uszkodzenia zwieracza źrenicy oraz jej struktury. Wady wzroku pacjenta przez ponad 6 lat nie były korygowane, mimo że ostrość wzroku do dali z najlepszą korekcją (+11,0 Dsph i -4,0 Dcyl) osiągnęła w jego przypadku wartość 0,9 (Snellen). Wykonano zabieg fiksacji przeztwardówkowej złożonego implantu korygującego brak tęczówki oraz bezsoczewkowość pooperacyjną. Zabieg ten połączono z założeniem szwu ciągłego na brzeg źrenicy, powodując jej trwałe zmniejszenie. Ostrość wzroku do dali, z korekcją +1,25 Dsph i -3,5 Dcyl osiągnęła wartość 1,0 (Snellen). Plastyka tęczówki pozwoliła uzyskać najlepszy efekt kosmetyczny, tj. zachować naturalny kolor tęczówki przy nieznacznie tylko zwiększonym nakładzie finansowym (ryc. 9).
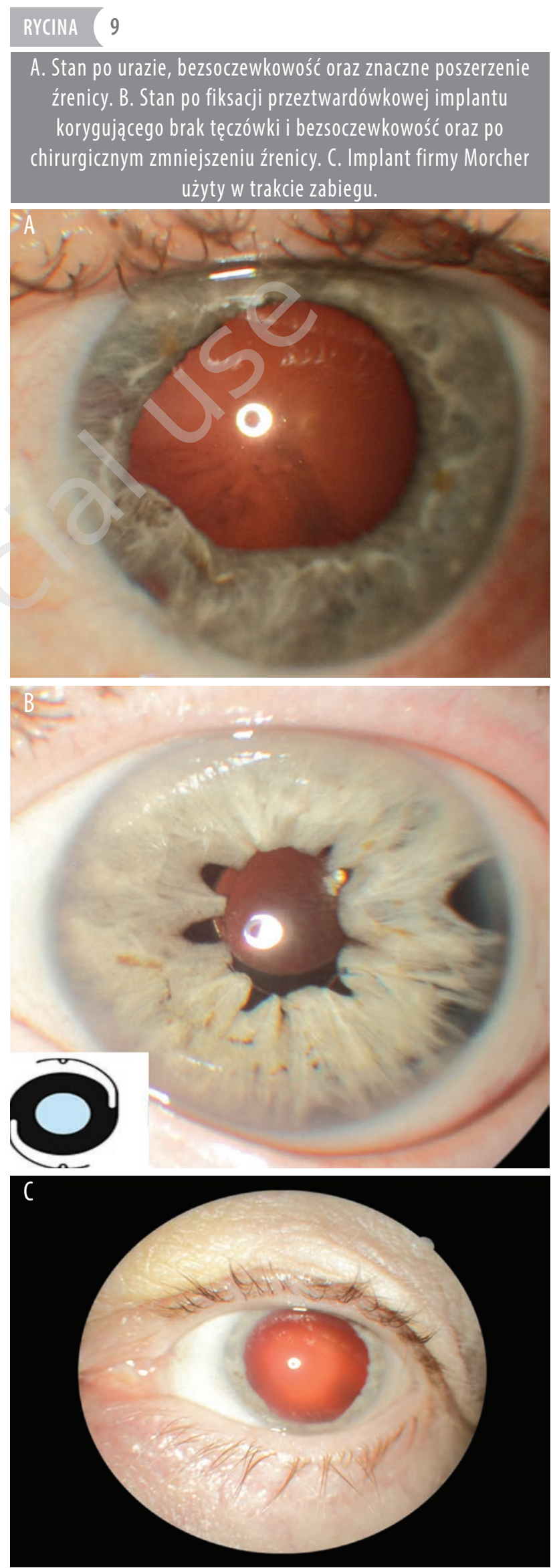


\section{POSUMOWANIE}

Chirurgia naprawcza oka z użyciem implantów tęczówkowych daje wiele możliwości korekcji jego niedoskonałości. Podobnie jak w przypadku leczenia każdego schorzenia lekarz powinien przedstawić pacjentowi każdą opcję terapii i zasugerować tę najkorzystniejszą, dającą najlepsze efekty lecznicze. Tylko wtedy pacjent pozna wszystkie opcje leczenia i będzie mógł w sposób świadomy dokonać właściwego wyboru. Nie powinno mieć znaczenia, czy korzysta on $\mathrm{z}$ konsultacji oraz leczenia $\mathrm{w}$ ramach posiadanego ubezpieczenia, czy leczy się odpłatnie. Proponowanie tylko najtańszej opcji leczniczej nie daje pacjentowi żadnej możliwości wyboru.

Źródto rycin: materiaty własne autora (Ślaski Ośrodek Leczenia Chorób Oczu) oraz zasoby firm Morcher oraz Reper (za zgoda).

\author{
ADRES DO KORESPONDENCJ \\ dr n. med. Adam Cywiński \\ Śląskie Centrum Leczenia Oczu \\ 44-240 Żory, ul. Okrężna 11 \\ e-mail: adamcyw@gmail.com
}

ORCID:

Adam Cywiński - ID - http://orcid.org/0000-0001-8732-7396

\section{Piśmiennictwo}

1. Kent Ch. The Artificial Iris In Practice. Rev Ophthalmol. 2019.

2. Cywiński A. Chirurgia plastyczna tęczówki. Część 1. Chirurgia bez użycia implantów tęczówkowych. OphthaTherapy. 2019; 4(24): $265-71$.

3. Cywiński A. Ferda-Lewińska D. Chirurgia plastyczna wrodzonego ubytku tęczówki modo Cywiński. OphthaTherapy. $2018 ; 5(1): 46-51$.

4. Miller KM. Prosthetic Iris Devices: Indications, Availability, Preoperative Planning, Clinical Examples, and Implantation Tips. AAO Clinical Education 2007.

5. Lin SR, Miller KM. Lessons Learned from Implantation of Morcher 50D and 96S Artificial Iris Diaphragms. Case Rep Ophthalmol. 2017; 8(3): 527-34.

6. Pozdeyeva NA. Pashtayev NP, Lukin VP et al. Artificial iris-lens diaphragm in reconstructive surgery for aniridia and aphakia. J Cataract Refract Surg. 2005; 31(9): 1750-9.

7. Mayer CS. Laubichler AE, Khoramnia $\mathrm{R}$ et al. Challenges and Complication Management in Novel Artificial Irislmplantation. J Ophthalmolol. 2018; 2018: 3262068.

Konflikt interesów:

Nie wystęuje.

Finansowanie:

Nie występuje.

Etyka:

Treści przedstawione w artykule są zgodne z zasadami Deklaracji Helsińskiej,

dyrektywami EU oraz ujednoliconymi wymaganiami dla czasopism biomedycznych.
Conflict of interest:

None.

Financial support:

None.

Ethics:

The content presented in the article complies with the principles of the Helsinki Declaration, EU directives and harmonized requirements for biomedical journals. 